\title{
Testing for Twin Deficits and Ricardian Equivalence Hypotheses: Evidence from Iran
}

\author{
*Farzane Bagheri1 ${ }^{1}$, Khosrow Piraee ${ }^{2}$, Salma Keshtkaran² \\ ${ }^{1}$ Department of Accounting, Dariun Branch, Islamic Azad University, Dariun, Iran \\ 2Islamic Azad University, Iran-Shiraz Branch, Iran \\ *farzane.bagheri64@gmail.com
}

\begin{abstract}
The main purpose of this study is to examine the relationship between budget deficit and current account deficit in Iran from 1971 to 2007. Twin deficits, which argues that a larger budget deficit leads to an expanded current account deficit, and Ricardian equivalence hypothesis, which states that there is no casual relationship between these two deficits, are examined for this purpose. To achieve this goal, Johansen co-integration and Granger causality tests are used for the period under study. The results indicate that there exists a long run equilibrium link between budget deficit and current account deficit. There is a one-way causality relationship from the budget deficit toward the current account deficit.
\end{abstract}

Key words: Twin deficits, Budget deficit, Current account deficit, Ricardian equivalence hypothesis.

\section{Introduction}

The main purpose of this paper is analysis the relationship between budget deficit and current account deficit in Iran's economy. Thus, this study tries to test the Ricardian equivalence, and the Keynesian proposition. The Ricardian equivalence argues that the budget and current account deficits are not correlated, whereas the Keynesian proposition confirms the existence of a positive relationship between the two deficits. In recent years, the twin-deficits hypothesis - the argument that budget deficits fuel current account deficits - has returned to the forefront of the policy debate. The argument first emerged in the 1980s under the "Reagan fiscal experiment", which marked a period of strong appreciation of the dollar and an unusual shift in the external balance of the United States. A similar pattern has also characterized countries such as Germany and Sweden, where the rise in the budget deficits of the early 90s was accompanied by a real appreciation of the national currency and a worsening in the current account (Branson, 1993). The coincidence of these events has given rise to a controversy on the causal links between the budget and current account balance, or "twin deficits" issue. In short, the controversy has reflected the two opposite views on fiscal policy prevailing in the literature. One was based on the traditional view that budget deficits have important and even harmful effects on the economy. The other was based on the Ricardian equivalence view that budget deficits have no effect at all.

\section{Literature Review}

In economic literature, many researches focused on the relationship between current account deficit (CAD, hereafter) and budget deficit (DEF, hereafter). The recent empirical investigations provide mixed results. Evans (1988), Miller and Russek (1989), Dewald and Ulan (1990), Enders and Lee (1990) and Kim (1995) supported the Ricardian equivalence, defined as budget and current account deficits are not correlated. Bernheim (1987) for example, raised questions regarding certain assumptions about the consumer behavior used to support the Ricardian equivalence hypothesis. On the other hand, Zietz and Pemberton (1990) examined the US data to find that DEF affects the CAD mainly through its impact on domestic absorption and income rather than through interest and exchange rates. In contrast, Abell (1990) also examined the US data but contended that the causation runs from the DEF through interest and exchange rates to the CAD. In this empirical work, Abell emphasized that there was no direct link between the two deficits. Authors such as Bahmani-Oskooee (1992, 1995), Rosensweing and Tallman (1993), Piersanti (2000), also found that there is a significant link between DEF and CAD mainly through interest rate and exchange rate channels. Fidrmuc (2003) using data from ten OECD countries, two emerging countries and six transition economies, confirmed the twin deficits hypothesis but with some noticeable differences between the result of the 1980s and those of the 1990s. While most of the studies focused on the experience of the developed countries, little attention has been given to developing economies. Among a few exceptions are Islam's finding (1998), for Brazil, which is indicated the presence 
of bilateral causality between trade deficit and budget deficit. Anoruo and Ramchander (1998) results, contrary to most findings in the literature, found trade deficit caused budget deficit and was not vice versa in five developing Southeast Asian economies-namely, India, Indonesia, Korea, Malaysia and the Philippines and Alkswani (2000) provided empirical evidence on reverse causation between the two deficits for Saudi Arabia. Saleh, Nair and Agalewatte (2005) explored twin deficits phenomenon in the case of Sri Lanka. Their empirical analysis in this paper supported the Keynesian view that there is a longrun relationship between current account imbalances and budget deficit.

The empirical results also showed that the direction of causality runs from the budget deficit to the current account deficit. Corsetti \& Müller (2006) showed that the likelihood and magnitude of twin deficits increases with the degree of openness of an economy, and decreases with the persistence of fiscal shocks. They take this insight to the data and investigate the transmission of fiscal shocks in a vector autoregression (VAR) model estimated for Australia, Canada, the UK and the US. They find that in less open countries the external impact of shocks to either government spending or budget deficits is limited, while private investment responds in line with their theoretical prediction. These results suggest that a fiscal retrenchment in the US may have a limited impact on its current external deficit. Marinheiro (2008) concluded for the presence of a (weak) long-run relationship between the budget deficit and the current account deficit and found evidence in favor of a reverse Granger-causality running from the CAD to the DEF. Siddiqui (2010) investigated twin deficits in the case of Pakistan and found the long run relationship between budget deficit and trade deficit. Datta and Mukhopadhyay (2010) supported the Ricardian equivalence hypothesis for the economy of Maldives over the period of the study. An important point made by the above-mentioned authors was that the underlying dynamic relation between the twin deficits in developing world may vary across countries due to the disparity in their macroeconomic structure. This paper, unlike more other studies, is based on a principle. It investigates the relationship between the two deficits on petroleum economy where exports, government revenue, and income are closely linked with oil revenue. The relationship between budget and current account deficits will be analyzed by using two complementary approaches: Johansen co-integration and Granger causality tests. The structure of the paper is organized as follows. Section 2 addresses the Ricardian equivalence and the twin-deficit hypotheses. Section 3 illustrates the twin deficits trends in Iranian economy. Section 4 presents the empirical results for Iran. The conclusion is presented in the last part.

\section{Theoretical Framework}

There are some traditional theoretical explanations for the relation between the budget deficit (DEF) and the current account deficit (CAD). Firstly according to the Mundell-Fleming framework, an increase in the DEF induces an upward pressure on interest rates that, in turn, will cause capital inflows and an appreciation of the exchange rate, ultimately leading to an increase in the CAD (see for example, Kouassi, Mougou'e, \& Kymn, 2004). Secondly, according to the Keynesian absorption theory, an increase in the DEF would induce domestic absorption (an expansion of aggregated demand) and hence, an increase in imports, causing an increase or a worsening of the CAD. Despite this popular consensus, the effects of government debt and deficits on the economy are not obvious from either economic theory or statistical evidence. Besides, this traditional view is challenged by the Ricardian equivalence hypothesis of Barro $(1974,1989)$. Ricardian equivalence states that, for a given expenditure path, the substitution of debt for taxes has no effect on aggregate demand nor on interest rates. As a result, it implies that a tax increase would reduce the budget deficit but would not alter the external deficit, since altering the means that the government uses to finance its expenditures does not affect private spending nor national saving. Yet, when Ricardian equivalence does not hold, there is scope for a causality relationship between the current account deficit and the budget deficit.

The national account identity presents the theoretical basis of the relationship between DEF and CAD. From the national income accounts:

$$
\mathrm{GDP}=\mathrm{C}+\mathrm{I}+\mathrm{G}+\mathrm{X}-\mathrm{M}=\mathrm{C}+\mathrm{S}+\mathrm{T}
$$

Where: $\mathrm{C}$ is consumption, $\mathrm{G}$ is government spending, $\mathrm{I}$ is investment, $\mathrm{X}$ is export of goods and services, $\mathrm{S}$ is saving and $\mathrm{T}$ is taxes. Adding the accounting principle that leakages must equal injections, we can easily determine the conditions that would make these two deficits identical: 
To see the relation, from the income accounting identity, we get:

$$
(\mathrm{X}-\mathrm{M})=(\mathrm{T}-\mathrm{G})+(\mathrm{S}-\mathrm{I})
$$

Where:

$(\mathrm{X}-\mathrm{M})=\mathrm{TD}$ is the trade deficit

$(\mathrm{T}-\mathrm{G})=\mathrm{BD}$ is the budget deficit, and

$(\mathrm{S}-\mathrm{I})=\mathrm{SD}$ is the saving deficit.

In relation (3), the left hand side is the foreign deficit, and the right hand side is composed from two deficits: budget (or public) deficit and private saving deficit. The right hand side is also named domestic deficit. One of the most important analysis in economic literature is the analysis of the relationship between the budget deficit (domestic deficit) and current account deficit (foreign deficit), named as the twin deficit. Two approaches are known to explore the twin deficits phenomenon, the Ricardian Equivalence and the Keynesian conventional proposition. The Keynesian preposition argues that there is a positive relationship between current account and budget deficits. If the public saving is negative, then national saving will decrease. With a lower level of national saving, the interest rate should increase, which will lead to an increase in the exchange rate. An increasing exchange rate will worsen the trade balance. So, the Keynesian preposition states that the budget deficit leads to increase in the current account deficits. Unlike the Keynesian preposition, the Ricardian equivalence expects no causal impact from budget deficit to trade deficit. This approach reveals that the budget deficit is a result of a tax cut. Tax cut reduces public revenues and saving. This is temporary procedure. The decrease of the public saving will be compensated by an equal increase of private saving. The national saving will not be affected. Therefore, the budget deficit has no effect on the current account deficit. In fact, in the Ricardian model, the driving force behind the current account is the response of consumption to various shocks to the economy.

\section{Results}

This section presents the empirical results for Iran. It starts by presenting the data. It then shows the results of testing for the Ricardian equivalence and twin-deficits hypotheses.

The data: The data employed in this study are annual data (1971-2007). The main data source is the central bank of Islamic Republic of Iran dataset complemented with International Financial Statistics (IFS) of the International Monetary Fund (IMF). The external debt (GD) data is from the IFS. ${ }^{1}$

Unit root tests: The preliminary step of co-integration procedure is testing for the presence of a unit root in the series of interest. Thus, we first investigate the unit root properties of the data using ADF test statistics. The test results point uniformly to the presence of a unit root in the data, meaning that just the first difference of the series is stationary. In Perron's view point (1989), in performing unit root tests, special care must be taken if it is suspected that structural change has occurred. Perron's structural change test has been done, due to revolution, war years in Iran during 1971-2007. As far as the structural change test was concerned, any of time series data did not have structural breaks; as a result, the integration degrees of all of them were I (1). Table 1 shows the ADF test result, for the variables in levels and in first differences.

Ricardian equivalence: We start our tests for Iran with the testing of the Ricardian equivalence hypothesis. The empirical literature on the RE hypothesis is vast and ever increasing. Most studies centre

1. There is no external debt data for years 1978, 1984, 1985; therefore, "Spine Interpolation" method has been used for their calculation. 
their attention on the reaction of private consumption to government financing decisions. We estimate the link between budget deficits and both private consumption and the current account deficit by using the equations, namely the specification of Bernheim (1987).

$$
C U_{t}=\beta_{1}+\beta_{2} D E F_{t}+\beta_{3} G C_{t}+\beta_{4} G D_{t}+\beta_{5} Y G_{t}+\beta_{6} P G_{t}+e_{1 t}
$$

And

$$
C A D_{t}=\alpha_{1}+\alpha_{2} D E F_{t}+\alpha_{3} G C_{t}+\alpha_{4} G D_{t}+\alpha_{5} Y G_{t}+\alpha_{6} P G_{t}+e_{2 t}
$$

Where CU is private consumption,

DEF is the budget deficit,

$G C$ is government consumption,

$\mathrm{G} D$ is external debt,

$Y G$ is GDP growth,

$P G$ is population growth, and $C A D$ is the current account deficit.

Table 1: the ADF test

\begin{tabular}{lll}
\hline Variable & level & First differences \\
\hline DEF & -2.42 & -7.34 \\
CU & -0.72 & -3.62 \\
GC & -1.14 & -3.62 \\
GD & 3.01 & -3.72 \\
PG & -0.82 & -5.96 \\
YG & -2.77 & -7.15 \\
GDP & 2.08 & -3.63 \\
CAD & & -5.43 \\
\hline
\end{tabular}

Source: Authors' calculations. Notes: In ADF test, we assume that the data have a constant and a linear trend. The lags for ADF test were chosen based on SIC. The critical values at the $5 \%$ significance level of (Hamilton, 1994) are (-2.93) and (-3.56) for the ADF test in the level and the first differences.

Private consumption, budget deficit, government consumption, public debt and current account deficit are measured as ratios over GDP.

Our focus is on the coefficients $\beta_{2}$ and $\alpha_{2}$. The pure Ricardian view predicts:

$\beta_{2}=\alpha_{2}=0$, that is, neither consumption nor the current account should respond to changes in the budget deficit. According to the twin-deficits hypothesis, we should instead observe $\beta 2>0$ and

$\alpha_{2} \succ 0$ because consumption and the current account deficit should increase in response to an increase in the budget deficit.

Wald test results are shown in Table 2 and don't confirm that: $\beta_{2}=\alpha_{2}=0$

Table 2: Wald test result

\begin{tabular}{cll}
\hline Chi-Square & Degrees of freedom & Prob. \\
\hline 6.75 & 2 & 0.032 \\
$H_{0}: \beta_{2}=\alpha_{2}=0$ & & \\
\hline
\end{tabular}

Source: Authors' calculations.

All in all, the data does not point to the validity of Ricardian equivalence for Iran, meaning that an increase in the deficit, for a given expenditure path, is not fully compensated by an increase in private saving. As a result an increase in the budget deficit could motivate the need of increased external financing, leading to a twin-deficit phenomenon. We will formally test this hypothesis in the next section.

Twin deficits: We estimate the link between budget deficits and both private consumption and the current account deficit by using the equations:

$$
C A D_{t}=\alpha_{1}+\alpha_{2} D E F_{t}+\alpha_{3} G C_{t}+\alpha_{4} G D_{t}+\alpha_{5} Y G_{t}+\alpha_{6} P G_{t}+e_{2 t}
$$




$$
C U_{t}=\beta_{1}+\beta_{2} D E F_{t}+\beta_{3} G C_{t}+\beta_{4} G D_{t}+\beta_{5} Y G_{t}+\beta_{6} P G_{t}+e_{1 t}
$$

Our estimation strategy involves linking consumption behavior to budget balances, both of which are measured as shares of GDP, by controlling for changes in other fiscal variables (government consumption and public debt) and in other variables traditionally associated with consumption behavior (income growth and population growth).

Having determined that the variables are first-differenced stationary and thus they have the same order of integration, we used tests suggested by Johansen $(1988,1991)$. In the first stage, the order of lag length is obtained from unrestricted vector autoregressive (VAR) via Schwartz Bayesian Criteria and Akaike Information Criteria. Since we have a few observations, we will just use Schwartz Bayesian Criteria. The progression of lag selection on the basis of VAR gives the following results:

Table 3: VAR lag order selection criteria for CU model

\begin{tabular}{clll}
\hline Order of lag & AIC & SC & HQ \\
\hline 0 & -18.07967 & -17.81032 & -17.98782 \\
1 & -25.13283 & $-23.24733^{*}$ & $-24.48982^{*}$ \\
2 & $-25.19831^{*}$ & -21.69666 & -24.00414 \\
\hline
\end{tabular}

Source: Authors' calculations.

Table 4: VAR lag order selection criteria for CAD model

\begin{tabular}{clll}
\hline Order of lag & AIC & SC & HQ \\
\hline 0 & -20.60192 & -20.33257 & -20.51006 \\
1 & $-25.45431^{*}$ & $-23.56881^{*}$ & $-24.81130^{*}$ \\
2 & -25.42013 & -21.91848 & -24.22597 \\
\hline
\end{tabular}

Source: Authors' calculations.

* indicates lag order selected by the criterion

AIC: Akaike information criterion

SC: Schwarz information criterion

HQ: Hannan-Quinn information criterion

We applied the Johansen's trace and maximum eigenvalue ( $\lambda-\max )$ tests to determine whether the variables in each system are cointegrated, and if so, how many cointegrating vectors would be identified from the system. Cheung and Lai (1993) suggest that the trace test shows more robustness to skewness and excess kurtosis in the residual rather than the maximum eigenvalue test. It is also robust to departures from hetroskedasticity (Johansen, 1995). The Johansen test results are shown in Table 5. The estimation was done as before using a lag length of one.

Table 5: Johansen's tests for cointegration for Bernheim's (1987) functions

\begin{tabular}{lllllllll}
\hline \multicolumn{2}{c}{ CU equation } & \multicolumn{7}{c}{ CAD equation } \\
\hline H0 & H1 & Trace & $\begin{array}{l}\mathbf{5 \%} \\
\text { value }\end{array}$ & Critical & H0 & H1 & Trace & $\begin{array}{l}\mathbf{5 \%} \\
\text { value }\end{array}$ \\
\hline$r=0$ & $r \geq 1$ & 142.01 & 95.75 & & $r=0$ & $r \geq 1$ & 146.33 & 146.33 \\
$r \leq 1$ & $r \geq 2$ & 75.75 & 69.82 & $r \leq 1$ & $r \geq 2$ & 83.43 & 83.43 \\
$r \leq 2$ & $r \geq 3$ & 48.47 & 47.86 & $r \leq 2$ & $r \geq 3$ & 50.01 & 50.01 \\
$r \leq 3$ & $r \geq 4$ & 27.83 & 29.8 & $r \leq 3$ & $r \geq 4$ & 25.18 & 25.18 \\
\hline
\end{tabular}

Source: Authors' calculations.

Notes: A lag length of one is used on the VAR $(p=1)$. Trace test indicates 3cointegration eqn(s) at the 0.05.level.

At the $5 \%$ significance level, the trace test indicates the presence of three cointegrating vectors. Finding of cointegration indicates that there is a stable long-run relation among the variables in the system. Bahmani-Oskooee and Brooks criteria is used for selecting optimal vector. The second vectors for both models are optimal. This method enables us to select a single-equation cointegration vector. The results are shown in Table 6. The coefficients of budget deficit on both the consumption and current account 
deficit model are positive. This finding supports the argument that consumption and current account deficit respond to fiscal policy changes. There is evidence in favor of a twin deficit.

Granger Causality test: Johansen co-integration method only confirms the existence (or absence) of a long run equilibrium relationship between two variables and does not say which of the one variable cause the other. The Ganger causality tests help to determine the direction of causality between two deficits. The empirical result of Granger's test is presented in table 7.

\section{Figure1: Cointegrating vectors in $\mathrm{CU}$ model}

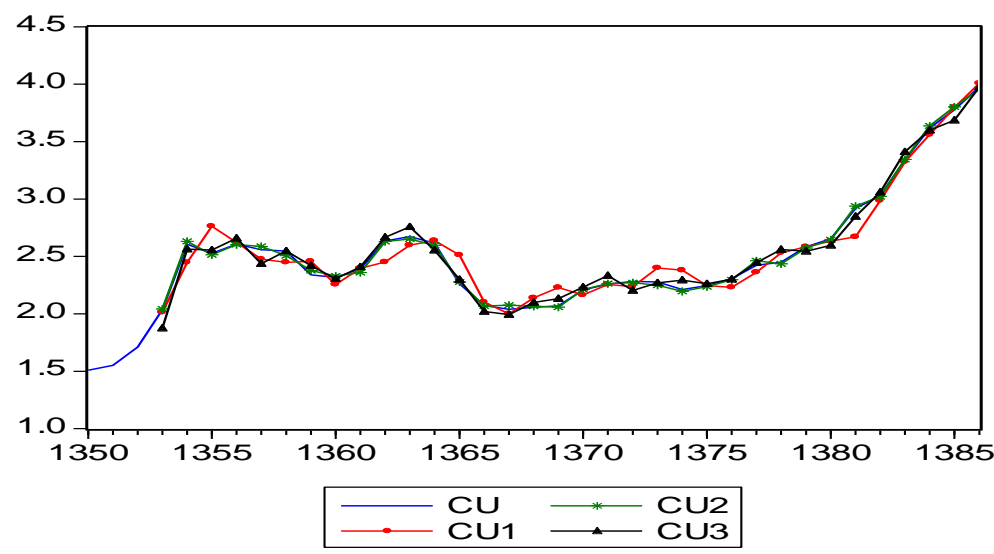

Figure 2: Cointegrating vectors in CAD model

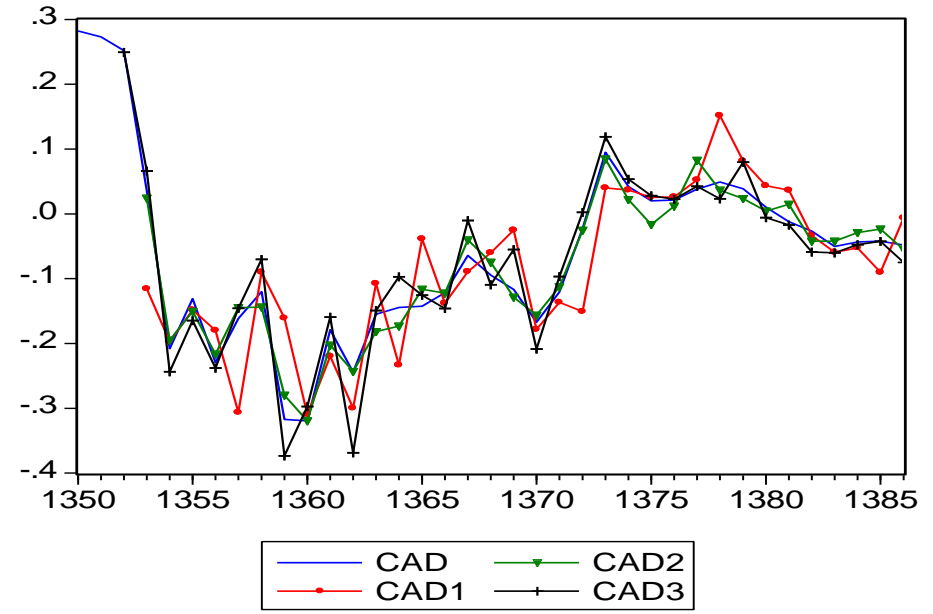

Table 6: Cointegration vectors

\begin{tabular}{lll}
\hline $\begin{array}{c}\text { Dependent Variables } \\
\text { Independent variables }\end{array}$ & Consumption/GDP & Current account deficit/ GDP \\
\hline Budget deficit & 33.56 & 36.88 \\
Government consumption & -1.77 & -2.86 \\
Public debt & 12.06 & 22.11 \\
Income growth & 59.95 & -19.38 \\
Population growth & -28.82 & -26.42 \\
\hline
\end{tabular}

Source: Authors' calculations.

Table 7: Granger-causality test

\begin{tabular}{llc}
\hline Null hypothesis & F-statistic & Prob. \\
\hline DEF does not Granger causes CAD & 5.86 & 0.001 \\
CAD does not Granger causes DEF & 1.71 & 0.18 \\
\hline
\end{tabular}

Source: Authors' calculations. 
Based on Table 7 the hypothesis that budget deficit does not Granger-cause current account deficit is rejected.

\section{Conclusion}

In this paper we analyzed the relationship between budget deficit and current account deficit in Iran. Thus, this study tried to test the Ricardian equivalence, and the Keynesian proposition. The Ricardian equivalence argues that the budget and current account deficits are not correlated, whereas the Keynesian proposition confirms the existence of a positive relationship between the two deficits. If the twin deficits hypothesis were valid, the appropriate policy prescription to correct a current account deficit would be a tax increase. However, such a policy prescription would be completely ineffective if Ricardian equivalence were a valid description of reality. To achieve our goal, Johansen co-integration and Granger causality tests were used. The results indicate that there exists a long run equilibrium link between budget deficit and current account deficit. There is a one -way causality relationship from the budget deficit toward the current account deficit. The empirical results rejected the validity of Ricardian equivalence hypothesis for Iran: This means that fiscal policy is effective at stabilizing the business cycle, and opens the scope for a twin deficit. Due to the basic source of income, in oil based economy, in particular Iran, is the oil export revenue; this revenue affects the government revenues and the exports of goods and services. Considering the important role of oil revenue of the components of the trade accounts and the public budget, we expected a positive relationship among budget deficit and trade deficit and policy efforts should be directed primarily to the reduction of the budget deficit. It is suggested that the government should curtail its non productive expenditures in order to reduce its budget deficit.

Acknowledgements: We would like to thank, without implicating, an anonymous referee for several helpful suggestions that helped improve the paper. Thanks also go to Maryam Barzegar for useful suggestions.

\section{References}

Abell, J. (1990). Twin Deficits during the 1980s: An Empirical Investigation. Journal of Macroeconomics, 12(1), 81-96.

Alkswani, M. (2000).The Twin Deficits Phenomenon in Petroleum Economy: Evidence from Saudi Arabia. In Paper presented at the seventh annual conference, economic research forum (ERF).

Anoruo, E. \& Ramchander, S. (1998). Current Account and Fiscal Deficits: Evidence from Five Developing Economies of Asia. Journal of Asian Economics, 9, 487-501.

Bahmani-Oskooee, M. (1992). What are the Long-Run Determinations of the US Trade Balance? Journal of Post Keynesian Economics, 14, 85-97.

Bahmani-Oskooee, M. (1995). The Long-Run Determinations of the US Trade Balance Revisited? Journal of Post Keynesian Economics, 17, 457-65.

Barro, R. (1974). Are Government Bonds Net Wealth? Journal of Political Economy, 82(6), 1095-1117.

Barro, R. (1989). The Ricardian Approach to Budget Deficits. Journal of Economic Perspectives, 3(2), 3752.

Bernheim, B. (1987). Ricardian Equivalence an Evaluation of Theory and Evidence with Three Comments. NBER Macroeconomics Annual, 263-315.

Branson, W. (1993). World Interest Rate and the DM with Germany Unification. Paper Prepared for a Symposium in Honor of Heinz Konig, Manheim, January.

Cheung, Y. \& Lai, K. (1993). Finite-Sample Sizes of Johansen's Likelihood Ratio Tests for Cointegration. Oxford Bulletin of Economics and Statistics, 55, 313-328.

Corsetti, G. \& Muller, G. (2006). Twin deficits: squaring theory, evidence and common sense. Economic Policy, 48, 597-638.

Darrat, A. (1988). Have Large Budget Deficits Caused Rising Trade Deficits? Southern Economic Journal, $52,879-887$.

Datta, K. \& Mukhopadhyay, C. K. (2010). Twin Deficits Phenomenon in Maldives: Spectral and Time Domain Analysis of Time Series. The IUP Journal of Applied Economics, 5(2), 98-125.

Dewald, W.G. \& Ulan, M. (1990).The Twin Deficit Illusion. Cato Journal, 10, 689-707.

Enders, W. \& Lee, B. (1990). Current Account and Budget Deficit: Twins or Distant Cousins? The Review of Economics and Statistics, 72(3), 373-381. 
Evans, P. (1988). Do Budget Deficits Affect the Current Account? Unpublished Paper, Ohio State University.

Fidrmuc, J. (2003). The Feldstein-Horioka Puzzle and Twin Deficits in Selected Countries. Economics of Planning, 36, 135-152.

Hamilton, J. (1994). Time series analysis. Princeton, NJ: Princeton University Press.

Islam, F. (1998). Brazil’s Twin Deficits: An Empirical Examination. Atlantic Economic Journal, 26(2), 12128.

Johansen, S. (1988). Statistical Analysis of Cointegration Vectors. Journal of Economic Dynamics and Control, 12, 231-254.

Johansen, S. (1991). Estimation and Hypothesis Testing of Cointegrating Vectors in Gaussian Vector Autoregressive Models, Econometrica, 59, 1551-1581.

Johansen, S. (1995). Likelihood-Based Inference in Cointegrated Vector Autoregressive Models. New York Oxford University Press.

Kim, K. (1995). On the Long-run Determinants of the US Trade Balance: A Comment. Journal of Post Keynesian Economics, 17, 447-55.

Kouassi, E. \& Mougou'e, M. \& Kymn, K. (2004). Causality Tests of the Relationship between the Twin Deficits. Empirical Economics, 29, 503-525.

Marinheiro, C.F. (2008). Ricardian Equivalence, Twin Deficits and the Feldstein-Horioka Puzzle in Egypt. Journal of Policy Modeling, 30, 1041-1056.

Miller, S. M. \& Russek, F. S. (1989). Are the Twin Deficits Really elated?.Contemporary Policy Issues, 7, 91115.

Piersanti, G. (2000). Current Account Dynamics and Expected Future Budget Deficits: Some International Evidence. Journal of International Money and Finance, 19, 255-171.

Rosenweing, J.A. \& Tallman, E.W. (1993). Fiscal Policy and Trade Adjustment: Are the Deficits Really Twins?. Economic Inquiry, 31, 580-594.

Saleh, A.S. \& Nair, M. \& Agalewatte, T. (2005). The Twin Deficits Problem in Sri Lanka: An Econometric Analysis. South Asia Economic Journal, 6 (2), 165-191.

Siddiqui, M. (2010). Twin Deficits: An Empirical Analysis in the Case Pakistan. World Applied Sciences Journal , 8 (11), 1398-1400.

Zietz, J. \& Pemberton, K. (1990). The U.S. Budget and Trade Deficits: A Simultaneous Equation Model. Southern Economic Journal, 57, 23-34. 